\title{
Anti-PD1 Monoclonal Antibody AGEN2034
}

National Cancer Institute

\section{Source}

National Cancer Institute. Anti-PD1 Monoclonal Antibody AGEN2034. NCI Thesaurus.

Code C136465.

A monoclonal antibody directed ag ainst the negative immunoregulatory human cell surface receptor prog rammed cell death 1 (PD-1, PCD-1; PDCD1) protein, with potential immune checkpoint inhibitory and antineoplastic activities. Upon administration, anti-PD-1 monoclonal antibody AGEN2034 binds to PD-1, and thereby blocks its binding to the PD1 ligand programmed cell death-1 ligand 1 (PD-L1), and prevents the activation of its downstream signaling pathways. This may restore immune function through the activation of cytotoxic T-cells. PD-1, a transmembrane protein in the immunog lobulin superfamily expressed on activated T-cells, negatively regulates $\mathrm{T}$-cell activation and effector function when activated by its ligand; it plays an important role in tumor evasion from host immunity. 